\title{
PENINGKATAN KEMAMPUAN MENULIS TEKS TANTANGAN MELALUI MODEL PROBLEM BASED LEARNING PADA PESERTA DIDIK KELAS IX D SEMESTER II SMP NEGERI 1 TANJUNG, BREBES \\ TAHUN PELAJARAN 2016 / 2017
}

\author{
SUHENDRO \\ SMP Negeri 1 Tanjung, Brebes \\ Email : hendro0568@gmail.com
}

\begin{abstract}
ABSTRAK
Tujuan penelitian dengan menggunakan Model Problem Based Learning dalam proses pembelajaran adalah untuk mengetahui keberhasilan kemampuan menulis teks tantangan dan perubahan aktivitas peserta didik melalui penelitian tindakan kelas. Penelitian dilakukan dalam dua siklus. Data kuantitatif dianalisis secara deskriptif dengan menghitung rata-rata, dan persentase ketercapaian. Data kualitatif dianalisis dengan prosedur reduksi, paparan, dan simpulan. Hasil penelitan diperoleh (1) nilai rata-rata prasiklus 73 menjadi 82,86 pada siklus I dan 85,57 pada siklus II dengan ketuntasan $68,57 \%, 82,86 \%$, dan $97,1 \%$ dan (2) perubahan aktivitas peserta didik yang semakin responsif, konsentrasi, antusias, aktif, dan lebih optimis.
\end{abstract}

Kata kunci : Menulis, Teks Tantangan, Model Problem Based Learning

\section{PENDAHULUAN}

Menulis merupakan sebuah keterampilan berbahasa mengungkapkan sebuah gagasan, perasaan, dan juga pemikiran-pemikiran yang dimiliki kepada orang ataupun pihak lainnya dengan menggunakan sebuah media tulisan (Nurjamal,dkk. 2011). Adapun materi pelajaran bahasa Indonesia pada penelitian ini tentang menulis teks tantangan di kelas IX semestes 2 . Teks tantangan adalah sebuah teks yang isinya berupa informasi yang memuat bantahan/sanggahan terhadap suatu hal yang kontroversial yang sedang tumbuh di masyarakat yang dilengkapi dengan argumen dan data-data yang dapat memperkuat bantahan tersebut. Teks tantangan ini biasanya ada dan menjadi penyangga dalam debat. Dalam kemdikbud (2015: 135) struktur teks tantangan ada tiga, yaitu isu, argumen, dan simpulan. Tim edukatif (2013: 120) menjelaskan bahwa teks tantangan dapat diklasifikasikan berdasarkan bentuknya, yaitu berupa esai dan surat pembaca.

Sebagai salah satu keterampilan berbahasa, terutama keterampilan menulis,teks tantangan merupakan salah satu kompetensi dasar yang harus dipelajari oleh peserta didik SMP kelas sembilan. Kompetensi dasar yang dimaksud adalah: menyusun teks eksemplum, tanggapan kritis, tantangan, dan rekaman percobaan sesuai dengan karakteristik teks yang akan dibuat secara lisan dan tulisan (Silabus Bahasa Indonesia Kelas IX Semester 2). Sesuai dengan indikator di atas, jelaslah bahwa peserta didik SMP kelas sembilan semester genap dituntut untuk: 1) mampu menentukan tema teks tantangan; 2) mampu mengembangkan tema menjadi kalimat-kalimat tersebut menjadi teks tantangan dengan memperhatikan ketepatan struktur. Indikator tersebut mengisyaratkan bahwa peserta didik mampu menyusun teks tantangan dengan memperhatikan kaidah bahasa.

Kenyataan di lapangan, para peserta didik belum mencapai hasil belajar yang optimal untuk materi ini. Terbukti hasil tes kompetensi materi menulis teks tantangan masih sangat rendah, yaitu rata-rata 73 dan ketuntasan belajar klasikalnya hanya 42,85\%. Hal ini terjadi karena strategi pembelajaran yang kurang tepat. Guru masih menjelaskan tentang teoritis dan pembelajaran lebih bersifat teacher-centered dengan alasan klasik kekurangan waktu. Di samping itu, lingkungan belajar di kelas tersebut kurang tertib dan ramai dikarenakan pengelolaan kelas yang belum optimal.

Dari faktor peserta didik, rendahnya hasil belajar disebabkan karena tingkat aktivitas belajar peserta didik rendah. Pelajaran bahasa Indonesia khususnya dalam menentukan 
menulis dianggap sulit, membosankan dan tidak menarik. Peserta didik bahkan tidak mampu menghubungkan antara apa yang mereka pelajari dengan bagaimana pengetahuan tersebut akan dipergunakan/dimanfaatkan. Aktivitas peserta didik dalam kegiatan pembelajaran kurang baik. Dalam kegiatan belajar mengajar maupun dalam penugasan peserta didik cenderung pasif. Peserta didik saling menunggu temannya untuk mengerjakan tugas dan beberapa peserta didik sama sekali tidak mau mengerjakan tugas dengan alasan tidak bisa atau tidak membawa buku. Bahkan beberapa peserta didik sengaja lebih memilih bercakap-cakap atau bermain-main dengan teman dibandingkan dengan mengerjakan tugas.

Hal lain yang menjadi penyebab hasil belajar rendah adalah suasana pembelajaran yang kurang kondusif. Tanggapan peserta didik terhadap materi menulis teks tantangan tidak maksimal. Peserta didik cenderung pasif, tidak menunjukkan aktivitas yang berarti untuk mengikuti pembelajaran ini. Akibatnya, peserta didik enggan untuk tampil menulis teks tantangan, kalaupun dipaksakan hasilnya tidak maksimal. Uraian tersebut menunjukkan bahwa pembelajaran menulis teks tantangan belum berhasil atau dapat dikatakan pembelajaran menulis teks tantangan mengalami kegagalan. Kegagalan ini merupakan masalah yang harus segera diatasi. Untuk mengatasi kegagalan tersebut, peneliti melakukan tindakan perbaikan dengan menggunakan model problem based learning pada pembelajaran menulis teks tantangan.

Problem Based Learning (PBL) adalah proses pembelajaran dalam kurikulumnya, dirancang masalah-masalah yang menuntut peserta didik mendapat pengetahuan penting, yang membuat mereka mahir dalam memecahkan masalah, dan memiliki model belajar sendiri serta memiliki kecakapan berpartisipasi dalam tim. Proses pembelajarannya menggunakan pendekatan yang sistemik untuk memecahkan masalah atau menghadapi tantangan yang nanti diperlukan dalam kehidupan sehari-hari. Dengan PBL akan terjadi pembelajaran bermakna. Peserta didik yang belajar memecahkan suatu masalah maka mereka akan menerapkan pengetahuan yang dimilikinya atau berusaha mengetahui pengetahuan yang diperlukan. Belajar dapat semakin bermakna dan dapat diperluas ketika peserta didik berhadapan dengan situasi di mana konsep diterapkan. Dalam situasi PBL, peserta didik mengintegrasikan pengetahuan dan keterampilan secara simultan dan mengaplikasikannya dalam konteks yang relevan. PBL dapat meningkatkan kemampuan berpikir kritis, menumbuhkan inisiatif peserta didik didik dalam bekerja, motivasi internal untuk belajar, dan dapat mengembangkan hubungan interpersonal dalam bekerja kelompok. Pembelajaran berbasis masalah merupakan salah satu pendekatan pembelajaran yang digunakan untuk merangsang berpikir tingkat tinggi siswa dalam situasi yang berorientasi pada masalah dunia nyata, termasuk di dalamnya bagaimana belajar oleh Ibrahim dan Nur $(2010: 2)$

Model Problem Based Learning merupakan salah satu solusi untuk meningkatkan kemampuan menulis teks tantangan. Pandangan tujuan tentang model PBL menurut Rusman (2010: 238) adalah penguasaan isi belajar dari disiplin heuristik dan pengembangan keterampilan pemecahan masalah. Hal ini sesuai dengan karakteristik model PBL, yaitu belajar tentang kehidupan yang luas, keterampilan memaknai informasi, kolaboratif, dan belajar tim, serta kemampuan berpikir reflektif dan evaluatif. Adapun menurut Arends ( 2008) bahwa: "Pembelajaran berbasis masalah bertujuan untuk membantu peserta didik mengembangkan terempilan berfikir dan keterampilan pemecahan masalah belajar, peranan orang dewasa secara autentik, memungkinkan peserta didik untuk mendapatkan rasa percaya diri atas kemampuan yang dimilikinya sendiri, untuk berfikir dan menjadi pelajar yang mandiri". Dengan model PBL ini, semua peserta didik akan melibatkan diri secara aktif dalam kegiatan pembelajaran, baik diterapkan secara individual maupun secara berkelompok. Di samping itu, peserta didik akan lebih bergairah dan bersemangat karena terasa lebih menyenangkan.

Tujuan dari penelitian ini adalah untuk mengetahui keberhasilan kemampuan menulis teks tantangan dan perubahan aktivitas peserta didik kelas IXD SMP Negeri 1 Tanjung 
Tahun Pelajaran 2016/2017 pada pembelajaran menulis teks tantangan dengan model problem based learning.

\section{METODE PENELITIAN}

Prosedur penelitian tindakan kelas terhadap pembelajaran menulis teks tantangan ini telah peneliti lakukan sebanyak dua siklus. Setiap siklus ditempuh melalui empat langkah. Menurut Arikunto (2008: 16) secara garis besar terdapat empat tahapan yang lazim dilalui dalam PTK, yaitu perencanaan, pelaksanaan, pengamatan, dan refleksi. Adapun model dan penjelasan untuk masing-masing tahap divisualisasikan dengan gambar 1 . berikut.

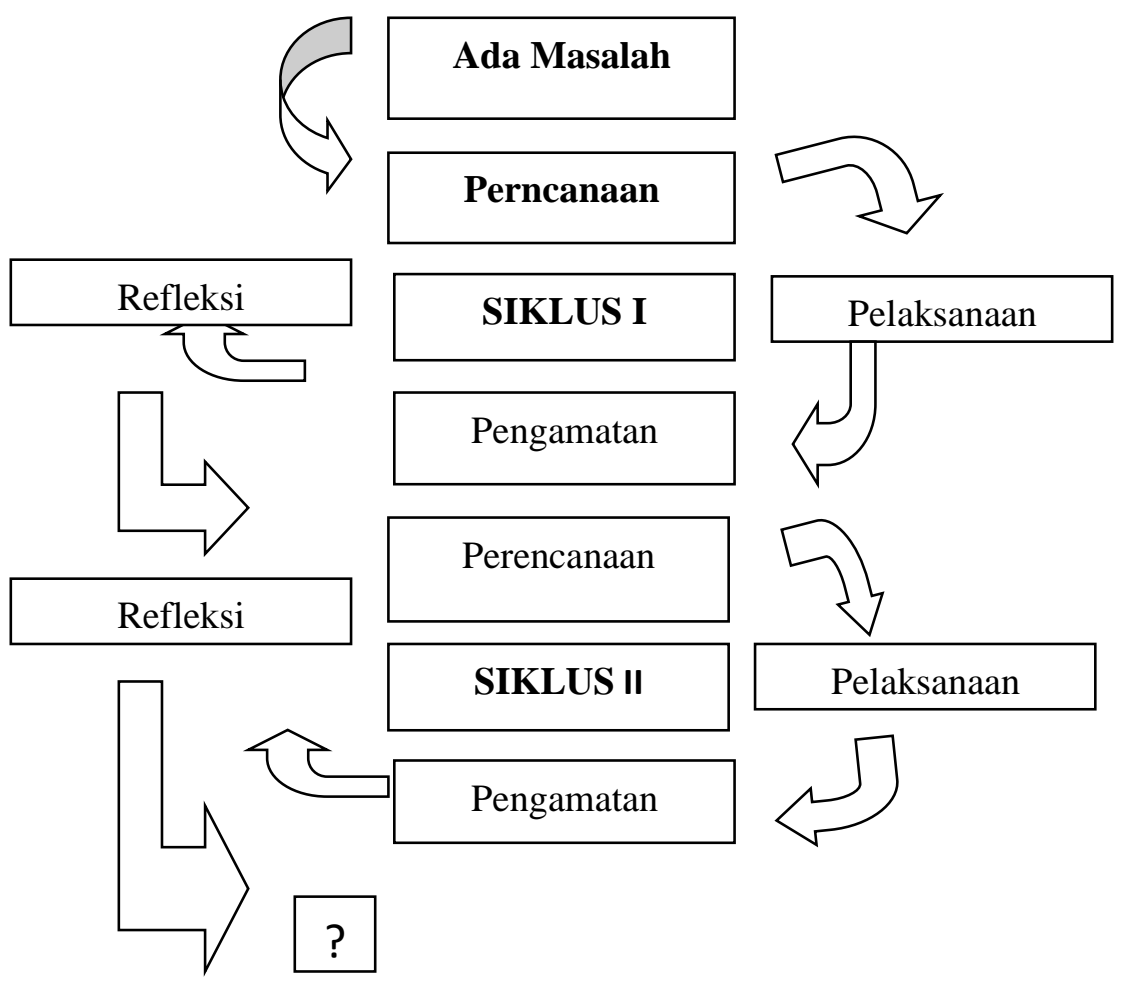

Gambar 1. Alur Penelitian PTK

Pada Kegiatan baik siklus I dan II, sebelum melaksanakan tindakan terlebih dahulu menyusun rencana pelaksanaan pembelajara (RPP), lembar kerja, dan merancang tes formatif. Penelitian dilaksanakan pada semester II (genap) tahun pelajaran 2016/2017. Lama kegiatan sekitar 2 bulan, mulai Bulan Januari sampai Bulan Februari. Tindakan siklus I dilaksanakan dalam dua pertemuan yaitu pada hari Senin, 16 Januari 2017, jam ke 4, 5. Sedangkan tindakan siklus II dilaksanakan pada hari Sabtu, 11 Februari 2017, jam ke- 3,4.

Langkah selanjuntnya pengumpulan data dari hasil lembar kerja dan tes tertulis yang dilakukan oleh peserta didik, hasil pengamatan dari teman sejawat, dan hasil dari pengumpulan angket yang dikerjakan oleh peserta didik pada akhir pembelajaran. Berdasarkan instrumen yang telah digunakan dalam penelitian ini, data yang diperoleh dapat dikelompokkan menjadi dua, yaitu data kuantitatif dan data kualitatif. Data kuantitatif yaitu berupa hasil tes peserta didik. Adapun data kualitatif yaitu berupa hasil nontes peserta didik, seperti catatan observasi pembelajaran, dan jawaban angket peserta didik. Data kuantitatif dari hasil tes dianalisis secara deskriptif dengan menghitung jumlah rata-rata dan persentase ketercapaian. Adapun data kualitatif diperoleh dari hasil observasi, angket, dan dokumentasi yang dianalisis dengan prosedur reduksi data, paparan data, dan simpulan. 


\section{HASIL DAN PEMBAHASAN}

\section{HASIL}

\section{Kondisi Awal :}

Kegiatan pembelajaran bahasa Indonesia pada materi teks tantangan di SMP Negeri 1 Tanjung khususnya kelas IXD sampai saat ini belum menampakkan suasana yang kondusif. Tampak sekali peningkatan kemampuan belajar peserta didik masih rendah. Rendahnya peningkatan kemampuan belajar peserta didik dapat diketahui setelah dilakukan pengamatan selama proses pembelajaran berlangsung. Hal ini terlihat pada saat pembelajaran berlangsung masih banyak peserta didik yang hanya duduk diam mendengarkan penjelasan guru, tanpa menunjukkan peningkatan kemampuan yang berarti. Hanya beberapa peserta didik saja yang aktif, sedangkan yang lain bersikap pasif, kurang bersemangat, dan sulit untuk berkonsentrasi sehingga suasana di dalam kelas terasa monoton dan membosankan. Strategi ini ternyata belum mendapatkan hasil yang diharapkan. Hal ini dapat dilihat dari hasil uji kompetensi pada kondisi awal, yaitu sebelum dilakukan tindakan memiliki nilai rata-rata sebesar 73,00 dengan ketuntasan belajar klasikal 68,57\%. Hal ini tampak pada tabel 1 berikut.

Tabel 1. Hasil Tes Pra Siklus

\begin{tabular}{|l|c|c|}
\hline \multicolumn{1}{|c|}{ Uraian } & Hasil & Keterangan \\
\hline Nilai Rerata & 73 & KKM : 75 \\
\hline Nilai Tertinggi & 80 & \\
\hline Nilai Terendah & 50 & \\
\hline Jumlah siswa & 35 & \\
\hline Jumlah siswa tuntas & 11 & \\
\hline \% Ketuntasan Klasikal & $68,57 \%$ & \\
\hline
\end{tabular}

Melalui hasil tes pra siklus tersebut diketahui bahwa tingkat kemampuan menulis menulis teks tantangan masih jauh di bawah kriteria ketuntasan minimal (KKM) yaitu 75 dan ketuntasan belajar klasikal $85 \%$. Untuk itu, peneliti melakukan Penelitian Tindakan Kelas pada materi menulis teks tantangan dengan menggunakan model Problem Based Lerning di kelas IX D semester 2 SMP N I Tanjung tahun pelajaran 2016/207.

Pelaksanaan Model Problem Based Learning untuk Meningkatkan Kemampuan Menulis Teks Tantangan

\section{Siklus I :}

Tindakan perbaikan pembelajaran kemampuan menulis teks tantangan melalui model problem based learning pada peserta didik kelas IX D SMPN 1 Tanjung telah peneliti lakukan melalui dua siklus. Tindakan siklus I dilaksanakan yaitu pada hari Senin, 16 Januari 2017. Adapun kompetensi dasar tentang menulis teks tantangan bertolak dari masalah yang pernah dialami dalam kehidupan peserta didik. Kegiatan pendahulan (10 menit) merupakan tahap oreintasi, guru menyampaikan salam dan dilanjutkan berdoa bersama. Guru menyampaikan pokok bahasan dan tujuan pembelajaran menulis teks tantangan. Bahan apersepsi guru menayangkan contoh-contoh teks tantangan. Peserta didik mengamati berkaitan masalah yang bisa ditemukan dalam teks tantangan. Pada kegiatan inti meliputi merupakan langkah-langkah kegiatan prsoses dalam menulis teks tantangan. Langkah-langkah tersebut antara lain, sebagai berikut: (1) peserta didik membentuk kelompok kecil dan membaca informasi, merancang jawaban sementara yang berisi tentang alternatif-alternatif untuk memecahkan masalah pernah alami dalam kehidupan, yaitu teks tantangan; (2) setiap kelompok mencari topik atau masalah tertentu sebagai dasar penulisan teks tantangan; (3) masing-masing kelompok memilih topik berdasarkan kesepakatan bersama; (4) selanjutnya mengembangkan topik tersebut menjadi sebuah kerangka karangan dengan memperhatikan struktur teks tantangan; (5) berdasarkan data tersebut, dikembangkan menjadi teks tantangan. 
Selajutntya setiap kelompok melakukan presentasi, kelompok yang lain memberikan apresiasi. Kegiatan selajutnya merangkum/membuat kesimpulan sesuai dengan masukan yang diperoleh dari kelompok lain. Aktivitas guru dalam kegiatan inti; memantau, membimbing, memberikan perhargaan serta masukkan kepada kelompok lain. Pada kegiatan penutup, guru bersama peserta didik menyimpulkan materi dan menyampaikan informasi tindak lanjut pembelajaran untuk pertemuan berikutnya dan diakhiri salam.

\section{Hasil Tes Siklus I :}

Proses pembelajaran pada siklus I, peneliti menggunakan model problem based learning. Materi siklus I menulis teks tantangan berdasarkan dari masalah yang pernah dialami dalam kehidupan. Untuk mengetahui kemampuan peserta didik dalam menguasai materi teks tantangan, peneliti mengadakan uji kompetensi peserta didik. Hasil uji kompetensi siklus I diperoleh nilai rata-rata 79,57 nilai tertinggi 90 , nilai terendah 65 , dan ketuntasan klasikal $82,86 \%$ sebagaimana tabel 2 berikut.

Tabel 2. Hasil Tes Siklus I

\begin{tabular}{|l|c|c|}
\hline \multicolumn{1}{|c|}{ Uraian } & Hasil & Keterangan \\
\hline Nilai Rerata & 79,57 & KKM : 75 \\
\hline Nilai Tertinggi & 90 & \\
\hline Nilai Terendah & 65 & \\
\hline Jumlah siswa & 35 & \\
\hline Jumlah siswa tuntas & 29 & \\
\hline \% Ketuntasan Klasikal & $82,86 \%$ & \\
\hline
\end{tabular}

Berdasarkan hasil tes siklus I ada peningkatan hasil uji kompetensi nilai rata-rata hasil belajar peserta didik jika dibandingkan dengan hasil belajar sebelumnya, yaitu sekitar 73 menjadi 79,57 (3) dan ketuntasan klasikal dari 68,57\% menjadi 82,86.

\section{Hasil Pengamatan (Observasi) Siklus I :}

Hasil pengamatan terhadap aktivitas guru dan peserta didik pada tindakan siklus I diperoleh gambaran sebagai berikut. Pada saat guru mengajukan pertanyaan apersepsi, hanya ada 2-3 peserta didik yang dapat merespons pertanyaan guru. Sebagian lainnya masih tidak mengerti materi pembelajaran dan ada beberapa peserta didik tidak memperhatikan atau memukul-pukul menja. Pada saat kegiatan diskusi, masih dijumpai anggota kelompok yang malas untuk bekerja sama. Hal itu tampak dari peserta didik yang masih bekerja sendirisendiri tanpa melibatkan anggota kelompok lain. Hanya beberapa kelompok yang tampak serius dalam kegiatan diskusi cara menulis teks tantangan yang benar.

Pada saat guru memberikan pertanyaan untuk dijawab secara lisan, peserta didik masih tampak ragu untuk tunjuk jari. Ada yang sudah tunjuk jari, tapi kemudian tidak jadi menjawab. Karena tidak ada yang berani tampil, peneliti memberikan motivasi kepada peserta didik. Akhirnya ada seorang peserta didik yang berani tampil memberikan jawaban secara lisan. Dalam mengerjakan tugas, peserta didik sudah dapat bekerja dengan tekun. Beberapa gangguan yang muncul masih dijumpai, di antaranya peserta didik ada yang berbicara dengan teman sebangku. Hasil pengamatan pada siklus I, masih dijumpai peserta didik pasif, malas, dan kerja kelompok belum maksimal. Guru dalam membagi kelompok belum merata sehingga kerja belum maksimal. Oleh karena itu, kekurangan pada siklus I akan diperbaiki pada siklus II. 


\section{Hasil Angket Peserta Didik Siklus I}

Dari pelaksanaan tindakan pada siklus I, peneliti menggunakan angket yang dibagikan kepada peserta didik. Dari angket pembelajaran menulis teks tantangan dengan menggunakan model Problem Based Learning, diperoleh hasil sebagai berikut: (1) peserta didik merasa senang mengikuti pembelajaran menggunakan model Problem Based Learning dalam menulis teks tantangan, (2) peserta didik merasa terbantu untuk dapat memahami materi menggunakan model Problem Based Learning dalam menulis teks tantangan, (3) peserta didik termotivasi untuk belajar lebih giat agar mencapai hasil yang memuaskan, (4) peserta didik berkeinginan selalu menjawab semua pertanyaan yang diajukan guru tentang materi menggunakan model Problem Based Learning teks tantangan, (5) Peserta didik dapat menggunakan model Problem Based Learning teks tantangan dengan percaya diri, cepat, dan tepat.

Berdasarkan paparan di atas dapat ditampilkan hasil angket peserta didik sebagai berikut: (1) Peserta didik yang sangat suka (SS) pada indikator 1, 2, 3, 4, 5, 6, 7, 8, 9, dan 10 sebanyak $21 \%$, (2) Peserta didik yang suka (S) pada indikator 1, 2, 3, 4, 5, 6, 7, 8, 9, dan 10 sebanyak 77,4\%.(3) Peserta didik yang kurang suka (KS) pada indikator 1, 2, 3, 4, 5, 6, 7, 8, 9, dan 10 sebanyak 10,8\% , (4) Peserta didik yang tidak suka (TS) pada indikator 1, 2, 3, 4, 5, $6,7,8,9$, dan 10 sebanyak $5,7 \%$

Mengingat peserta didik yang kurang suka dan tidak suka masih sebanyak $16,5 \%$, maka peneliti akan melakukan perbaikan di siklus II, diantaranya (1) pembagian alokasi waktu yang lebih proposional, (2) perhatian pada peserta didik lebih merata, dan (3) pembagian kelompok diskusi dengan memperhatikan karakteristik peserta didik.

\section{Refleksi Siklus I :}

Hasil refleksi pembelajaran siklus I diperoleh lima komponen pembelajaran yang perlu diperbaiki. Pertama, untuk memudahkan peserta didik menyerap materi menulis teks tantangan, perlu diterapkan langkah-langkah kegiatan pembelajaran yang tepat. Kedua dalam membagi kelompok diskusi perlu memperhatikan karakteristik peserta didik . Ketiga, untuk meningkatkan konsentrasi peserta didik, diperlukan kesungguhan dalam menyelesaikan materi teks tantangan perlu adanya bimbingan dan perhatian secara merata. Keempat, untuk meningkatkan kinerja peserta didik, guru lebih meningkatkan pantauan, bantuan, dan bimbingan. Kelima, untuk memberi arah berpikir peserta didik, diperlukan kinerja guru yang optimal dalam menyampaikan kegiatan pembelajaran dan penjelasan tentang cara mengerjakan lembar kerja peserta didik. Simpulan tersebut direalisasikan dalam RPP siklus II.

\section{Pelaksanaan Model Problem Based Learning untuk Meningkatkan Kemampuan Menulis Teks Tantangan \\ Siklus II :}

Tindakan siklus II dilaksanakan pada hari Sabtu, 11 Februari 2017, kompetensi dasar tentang menulis teks tantangan berdasarkan gambar. Kegiatan pembelajaran siklus II merupakan tindaklanjut kekurangan-kekurangan yang ditemukan sebelumnya, yaitu pada siklus I. Guru melaksanakan pembelajaran pada siklus II berdasarkan RPP sesuai dengan siklus I, hanya perlakuan guru dalam proses pembelajaran dari mulai pendahulan, kegiatan inti, dan penutup lebih intensif. untuk mengetahui meningkatnya kemampuan menulis, guru melaksanakan uji kompetensi pada pada siklus II.

\section{Hasil Tes Siklus II :}

Hasil uji kompetensi siklus II diperoleh nilai rata-rata 85,57 nilai tertinggi 95, nilai terendah 70, dan ketuntasan klasikal 97,1\% sebagaimana tabel 3 berikut. 
Tabel 3. Hasil Tes Siklus II

\begin{tabular}{|l|c|c|}
\hline \multicolumn{1}{|c|}{ Uraian } & Hasil & Keterangan \\
\hline Nilai Rerata & 85,57 & KKM $: 75$ \\
\hline Nilai Tertinggi & 95 & \\
\hline Nilai Terendah & 70 & \\
\hline Jumlah siswa & 35 & \\
\hline Jumlah siswa tuntas & 34 & \\
\hline \% Ketuntasan Klasikal & $97,1 \%$ & \\
\hline
\end{tabular}

\section{Hasil Pengamatan (Observasi) Siklus II :}

Hasil pengamatan terhadap aktivitas guru dan peserta didik pada tindakan siklus II dapat simpulkan peserta didik merespon pertanyaan guru. Peserta memahami meteri dan serta antusias. Kerja kelompok belajar sangat efektif. Guru dalam melaksanakan proses pembelajar sesuai RPP. Guru telah menguasai pelajaran dengan baik. Guru dapat mengorganisasikan dan mengarahkan peserta didik untuk mengerjakan materi menulis teks tantangan secara intensif. Guru mampu meningkatkan keterlibatan/partisipasi aktif pesrta didik dan dapat memanfaatkan sumber/media pembelajaran dengan baik.

\section{Hasil Angket Peserta Didik Siklus II :}

Adapun dari hasil angket diketahui bahwa aktivitas peserta didik di kelas ada perubahan positif. Hal dapat dilihat indikator yang menyatakan sangat suka dan suka pada pembelajaran menulis teks tantangan sebanyak $88 \%$ melalui model problem based learning.

\section{Pembahasan}

\section{Peningkatan Kemampuan dalam Belajar :}

Untuk mengetahui peningkatan kemampuan belajar peserta didik selama pembelajaran, peneliti membandingkan data pengamatan siklus I dan siklus II. Dari perbandingan tersebut diketahui bahwa pada siklus II peningkatan kemampuan belajar peserta didik lebih responsif terhadap pelaksanaan pembelajaran menulis teks tantangan, baik dari segi kuantitas maupun kualitas. Pada kegiatan inti, peningkatan kemampuan belajar peserta didik juga lebih responsif, lebih konsentrasi, lebih antusias, dan lebih aktif melakukan kegiatan pembelajaran.

Dari hasil analisis tersebut terdapat peningkatan persentase peningkatan kemampuan belajar peserta didik antara siklus I dan siklus II. Pada siklus I, peningkatan kemampuan belajar peserta didik rata-rata 79,6\% sedangkan pada siklus II sebesar 85,6\%. Ini berarti peningkatan kemampuan belajar peserta didik sebesar 7,53\% $\left(\frac{85,6-79,6}{79,6} \times 100 \%\right)$.

Tanggapan/sikap peserta didik terhadap pelaksanaan pembelajaran menulis teks tantangan juga mengalami peningkatan yang cukup berarti. Berdasarkan hasil analisis angket peserta didik terhadap pelaksanaan pembelajaran tersebut $87,9 \%$ peserta didik bersikap positif pada siklus I, sementara $99 \%$ peserta didik bersikap positif pada siklus II. Ini berarti ada peningkatan sikap positif peserta didik terhadap pelaksanaan pembelajaran menulis teks tantangan sebesar $12,62 \%\left(\frac{99-87,9}{87,9} \times 100 \%\right)$.

Kinerja guru dalam pelaksanaan pembelajaran dalam materi menulis teks tantangan pun mengalami peningkatan yang sangat berarti. Berdasarkan hasil analisis pengamatan kolaborator tentang kinerja guru terhadap pelaksanaan pembelajaran dari pendahulan, kegiatan inti, dan penutup pada siklus I terlaksana. Hasil skor perolehan 87,5 \%, sehingga tergolong kategori cukup sedangkan pada siklus II hasil skor $93,75, \%$ termasuk kategori baik sekali. 


\section{Perubahan Aktivitas Peserta Didik :}

Perbandingan data nontes dari hasil obsevasi, dan angket pada siklus I dan siklus II dilakukan untuk mengetahui perubahan aktivitas peserta didik selama mengikuti pembelajaran menggunakan model Problem Based Learning teks tantangan. Berdasarkan hasil observasi dan angket diketahui adanya perubahan aktivitas ke arah yang lebih baik. Hal itu dibuktikan oleh aktivitas peserta didik selama pembelajaran berlangsung. Hasil observasi menunjukkan bahwa pada siklus II, peserta didik lebih bersemangat dalam menggunakan model Problem Based Learning teks tantangan, lebih dapat bekerja sama dalam berdiskusi, lebih lancar dalam menggunakan model Problem Based Learning teks tantangan, lebih berani menjawab pertanyaan peneliti, dan tetap serius mengerjakan tugas.

Hasil angket diperoleh bahwa peserta didik mengaku sangat senang mengikuti pembelajaran, baik terhadap model pembelajaran maupun cara peneliti mengajar. Peserta didik pun memiliki pandangan lebih luas tentang model belajar. Sebelumnya, peserta didik hanya mengandalkan LKS yang dijadikan sumber belajar. Setelah diberlakukan siklus II, peserta didik mengaku memanfaatkan kerja sama antarteman sebagai sarana penunjang belajar.

\section{KESIMPULAN}

Tindakan yang dilakukan peneliti dengan menerapkan model problem based learning pada pembelajaran dapat meningkatkan kemampuan menulis. Hal ini dapat dari perbandingan hasil tes diperoleh bahwa sebelum tindakan dilakukan, ketuntasan belajar hanya mencapai $68,57 \%$, tetapi setelah tindakan siklus I ketuntasan klasikalnya mencapai 82,86 \% dan pada siklus II mencapai 85,57 \%. Dengan demikian, ketuntasan belajar pada siklus I meningkat $20,84 \%$ dan pada siklus II meningkat lagi 3,28 \%. Adapun nilai rata-rata pada prasiklus, siklus I, dan siklus II yaitu 73, 79,6 dan 85,6

Hasil observasi diperoleh adanya perubahan perilaku/aktivitas ke arah positif. Hal itu dibuktikan oleh keaktifan peserta didik selama pembelajaran berlangsung. Pada siklus II peserta didik lebih semangat dalam pembelajaran menulis teks tantangan, lebih aktif berdiskusi, lebih cepat dalam menentukan fitur bahasa, dan srtuktur teks tantangan, lebih berani menjawab pertanyaan guru, dan tetap serius mengerjakan tugas. Selain itu, peserta didik mengaku sangat senang mengikuti pembelajaran, baik terhadap cara maupun model guru mengajar. Peningkatan hasil tes dan perubahan perilaku peserta didik sebagaimana dipaparkan di atas menunjukkan bahwa hipotesis dalam penelitian ini telah terbukti. Dengan demikian, penggunaan model Problem Based Learning dapat diterima oleh peserta didik dan sangat efektif apabila diterapkan pada pembelajaran menulis teks tantangan.

\section{DATAR PUSTAKA}

Arends, Richard. 2008. Learning To Teach. Penerjemah: Helly Prajitno \& Sri Mulyani. New York: McGraw Hill Company.

Arikunto, Suharsimi, dkk. 2008. Penelitian Tindakan Kelas. Jakarta: Bumi Aksara.

Ibrahim, M. dan Nur, M. 2002. Pembelajaran Berdasarkan Masalah. Surabaya: UNESA University.

Kementerian Pendidikan dan Kebudayaan. 2015. Bahasa Indonesia Wahana Pengetahuan SMP/MTs Kelas IX. Jakarta: Kementerian Pendidikan dan Kebudayaan.

Nurjamal, dkk.2011. Terampil Berbahasa Menyusun Karya Tulis Akademik, Memandu Acara (MC-Moderator) dan Menulis Surat. Bandung: Alfabeta.

Rusman.2010. Model-model pembelajaran mengembangkan profesionalisme guru. Bandung : Raja Grapindo Persada.

Tim Edukatif. 2016. Mahir Berbahasa Indonesia untuk SMP/MTs Kelas IX. Jakarta: Erlangga. 